\title{
Geometric Analysis of Davaran Fault System, Central Iran
}

\author{
Ali Sistanipour1, Mehran Arian ${ }^{2 *}$ \\ ${ }^{1}$ Department of Geography, Yadegar-e-Imam Khomeini (RAH), Shahr-e-Rey Branch, Islamic Azad University, \\ Tehran, Iran \\ ${ }^{2}$ Department of Geology, Science and Research Branch, Islamic Azad University, Tehran, Iran \\ Email: Alisistanipour@yahoo.com
}

Received 14 May 2015; accepted 27 June 2015; published 30 June 2015

Copyright (C) 2015 by authors and Scientific Research Publishing Inc.

This work is licensed under the Creative Commons Attribution International License (CC BY). http://creativecommons.org/licenses/by/4.0/

(c) (i) Open Access

\begin{abstract}
One of the main faults of the Central Iran is Davaran Fault system which holds right-lateral strike slip with a pressure component. Contemporary activities of this fault signify the continuity of stresses up to now. Davaran fault system has extended parallel to Davaran Mountains. Most of the drainage networks of this region are located on trend of faults. The faults of this region are classified to 5 groups. These groups include conjugated faults of Riedel and Anti-Riedel (R, R'), normal faults (T), faults parallel with the major fault $(Y)$ and faults approximately parallel with the main fault (P). T Faults are normal faults with tension mechanism. By calculation of sinuosity (Smf) of northeast and southwest mountain fronts of the region and ratio of valley floor width of the rivers flowing in the region to their wall height (Vf), it is specified that this region is active in terms of uplift and tectonics. The rivers have deep valley. Tectonic activity in northeast front is more active than southwest mountain front.
\end{abstract}

\section{Keywords}

Davaran Fault, Tectonic Activity, Tension, Right-Lateral, Iran

\section{Introduction}

Davaran fault system has extended parallel to Davaran Mountains that is located in the west of Dasht-e-Lut of the Central Iran. This fault is directed from northwest to southeast and is in the west of N-S active fault of Nayband-Gowk. Ancient deposits, older than Quaternary in this region during different periods, have been folded repeatedly through stronger or weaker intensity. These structures are the results of important Alpine tectonic

\footnotetext{
*Corresponding author.
} 
movements, especially, tectonic movements of the late Cenozoic period. The study area is situated between $55^{\circ} 30^{\prime}$ longitude to $56^{\circ} 45^{\prime}$ and $30^{\circ} 15^{\prime}$ to $31^{\circ} 30^{\prime}$ latitude. The study area is located on the Naien-Kerman retro arc foreland basin [1]-[3]. Dominant structural trend in Naien-Kerman province (Figure 1) is NW-SE. From tectonics view, it contains a retro arc foreland basin on the north margin of Urmieh-Dokhtar magmatic arc (SE part). Davaran fault system has developed in this province that forms on southwest part of East-Central Iran microcontinent.

\section{Physiographic-tectonic zoning map of Iran's sedimentary basins}

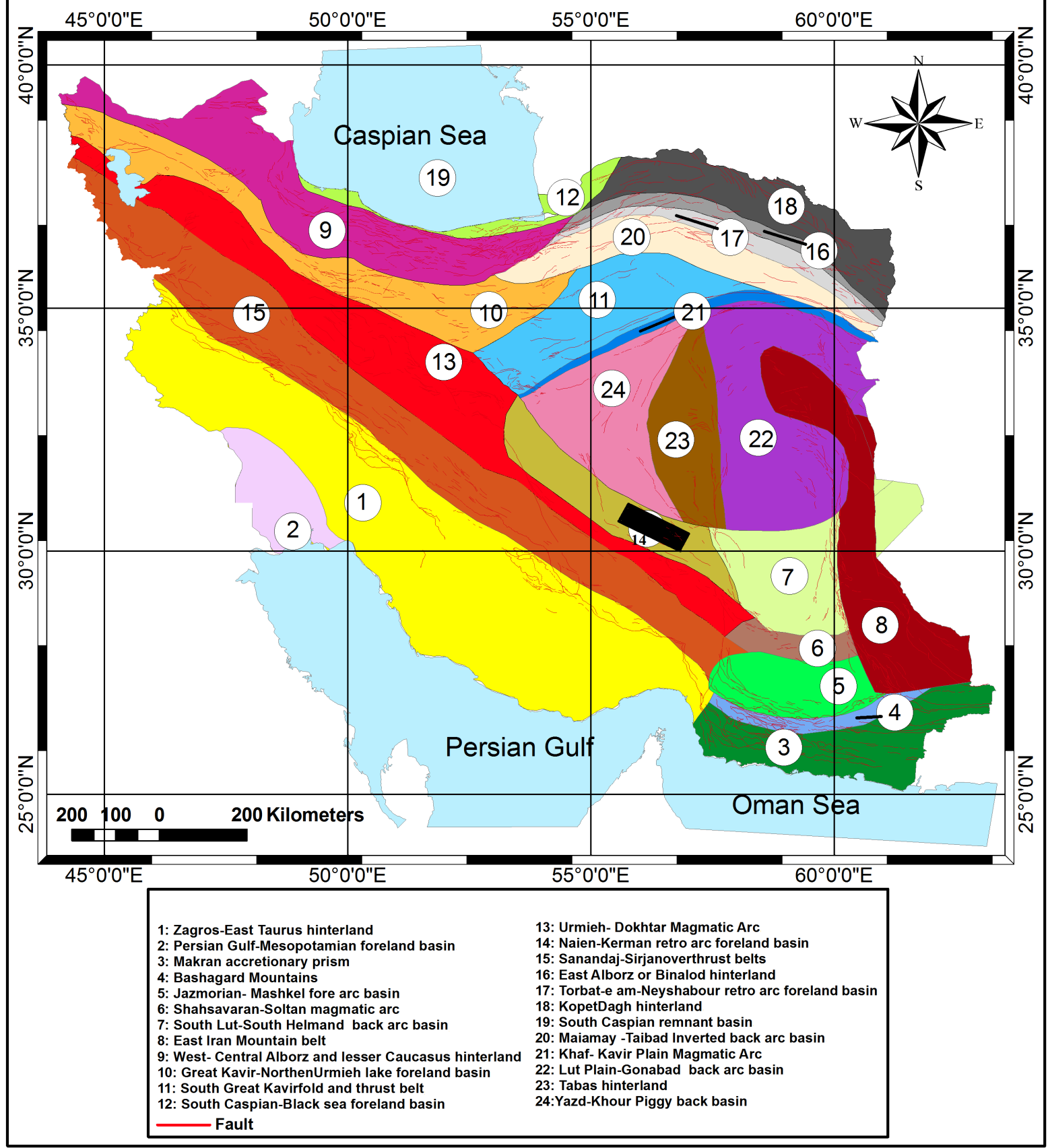

Figure 1. Physiographic-tectonic zoning map of Iran's sedimentary basins Iran modified from [1]. The study area is shown in the black rectangle. 


\section{Tectonic Setting of the Study Area}

The overall Arabia-Eurasia convergence is known from a combination of Africa-Eurasia and Arabia-Eurasia motions to be approximately N-S in Eastern Iran, with rates of about $30 \mathrm{~mm} /$ year at $50^{\circ} \mathrm{E}$ and $40 \mathrm{~mm} /$ year at $60^{\circ} \mathrm{E}$ [4]. Central Iran is a mosaic of various tectonic blocks once separated by minor ocean basins [5] that started to close in the mid-Tertiary [6]. Much of the broader collision zone, however, did not start to deform until the Mid-Miocene or even later [7]. In particular, major deformation of the Zagros folded belt appears that doesn't have begun until the Pliocene, approximate 5 Ma years ago or less [8], which is also the time at which there was a major re-organization of the sedimentation and deformation in the south Caspian Basin [9]. We suspect this time represents the final closure of any remaining ocean basins and the onset of true intra-continental shortening within Iran. We also expect that the present-day configuration of active faulting dates from roughly this time. [10] suggests that the Zagros accommodates about $10-15 \mathrm{~mm} /$ year of present-day shortening. This estimation is very dependent on the assumptions they made, but is roughly compatible with approximate $50 \mathrm{~km}$ of shortening which have occurred in the folded belt of Zagros over the last 5 Ma (Falcon, 1969 \& 1974). Thus we expect that $20-25 \mathrm{~mm} /$ year remains to be taken up north of the Zagros and to be represented as N-S shear in eastern Iran. This reasoning implies that a total of $100-125 \mathrm{~km}$ of right-lateral slip has occurred on the faults east and west of the Dasht-e-Lut over the last $5 \mathrm{Ma}$; the total offset may be more if the faults were active before $5 \mathrm{Ma}$. The available evidence is nonetheless sufficient to suggest that the probable slip rates (approximately 1 - 2 $\mathrm{mm} /$ year) and total offset (approximate $12 \mathrm{~km}$ ) on the Nayband-Gowk fault system are relatively small, and that most of the N-S shear between central Iran and Afghanistan is taken up on the eastern side of the Dasht-e-Lut [11].

Based on previous work on the salt and mud diapirism [12]-[22] and neotectonics regime in Iran [23]-[28], Zagros in south Iran is the most active zone [29]-[44]. Then, Alborz [45]-[78] and Central Iran [79]-[93] have been situated in the next orders.

\section{Materials and Methods}

The calculated geomorphic indices are suitable for assessment of tectonic activity of the study area. The geomorphic indices studies performed on the digital satellite data from the region and analyzing air photos and field work indicate that regional faults follow five main processes in right lateral shear zone, both in direction and in operation mechanism which may be formed in brittle shear zone (Figure 2 and Figure 3).

The first group of faults in the region is similar to "Y" faults in right lateral shear zone and has right lateral strike slip mechanism. They are formed in parallel direction with the main fault.

The second group has the same mechanism to the main fault but they make an angle of $15^{\circ}-20^{\circ}$ with the main fault in direction. The direction of these faults is in accordance with the direction of Riedel group in right lateral shear zone.

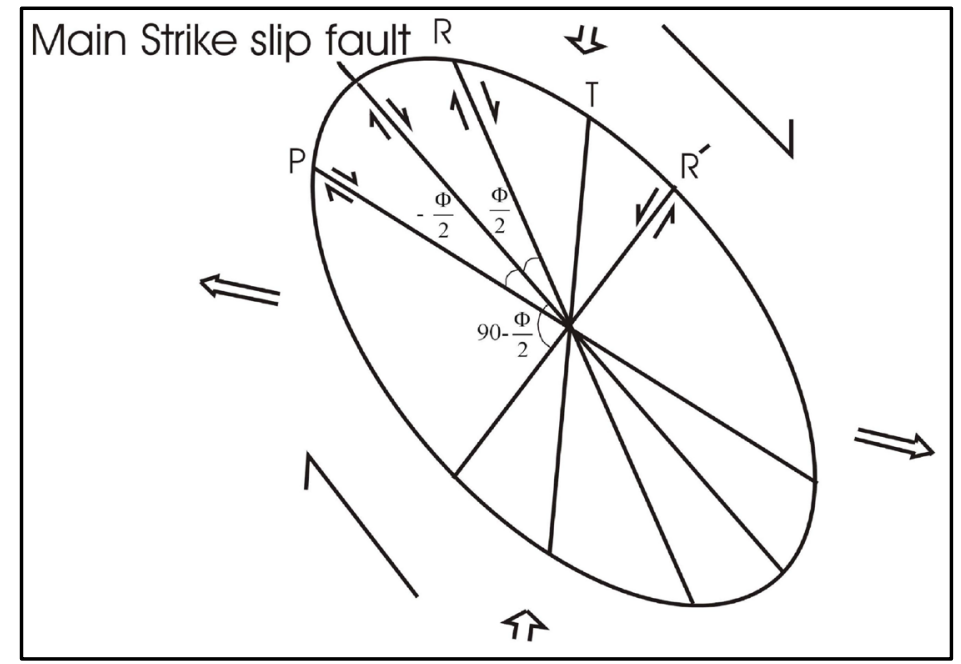

Figure 2. Strain ellipsoid in convergent right lateral zone with five fractures. 


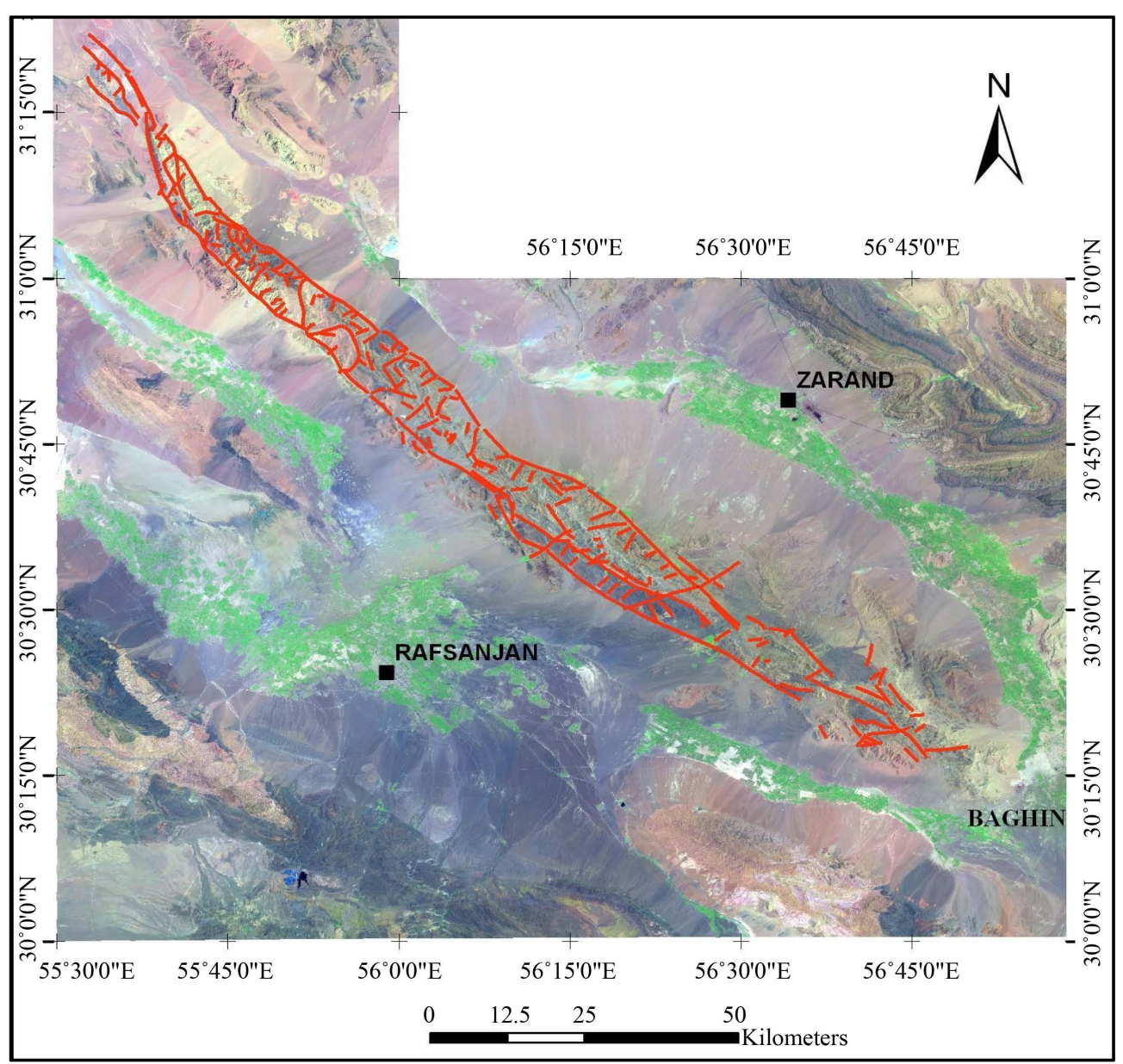

Figure 3. Davaran fault system in the processed satellite image (741).

The third group of faults holds left shear components and has an angle of $60^{\circ}$ to $80^{\circ}$ with the main fault in direction and they are similar to anti-Riedel faults in the right lateral shear zone. In the fourth group, the faults are at approximately $-10^{\circ}$ angle with the main fault in direction and have a similar mechanism with the main fault. Their direction is in accordance with the faults in group $\mathrm{P}$ in the right lateral shear zone. The fifth group of faults, directed at $\mathrm{AZ} 20^{\circ}$ to $0^{\circ}$, show normal mechanism. They are similar to the faults in group $\mathrm{T}$ in the right lateral shear zone.

These shapes and structures form in brittle shear zones and the complete conformity of regional faults with these fractures proves right lateral simple shear with pressure component which affects the region (Figure 2 and Figure 4).

In the other hand, most of drainage networks in Davaran mountain have been placed on the regional faults especially the fifth type faults (Figure 5).

The formulas of mountain front sinuosity (Smf) and ratio of valley floor width to its height ( $\mathrm{Vf}$ ) can be used in order to find active tectonic of the region by drainage network of the region (Figure 6 and Figure 7).

\subsection{Mountain-Front Sinuosity Index (Smf)}

This index represents a balance between stream erosion processes tending to cut some parts of a mountain front and active vertical tectonics that tend to produce straight mountain fronts. Index of mountain front sinuosity [94] is defined by:

$$
\mathrm{Smf}=\mathrm{Lj} / \mathrm{Ls}
$$

where $\mathrm{Lj}$ is the planimetric length of the mountain along the mountain-piedmont junction, and Ls is the straight- 


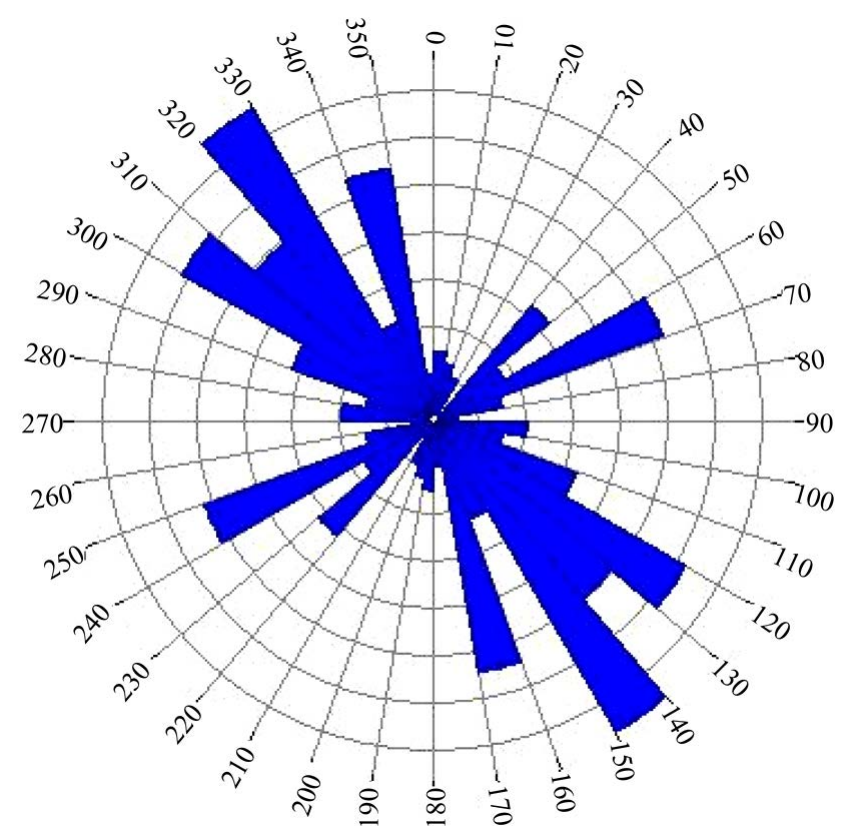

Figure 4. Rose diagram of regional faults.

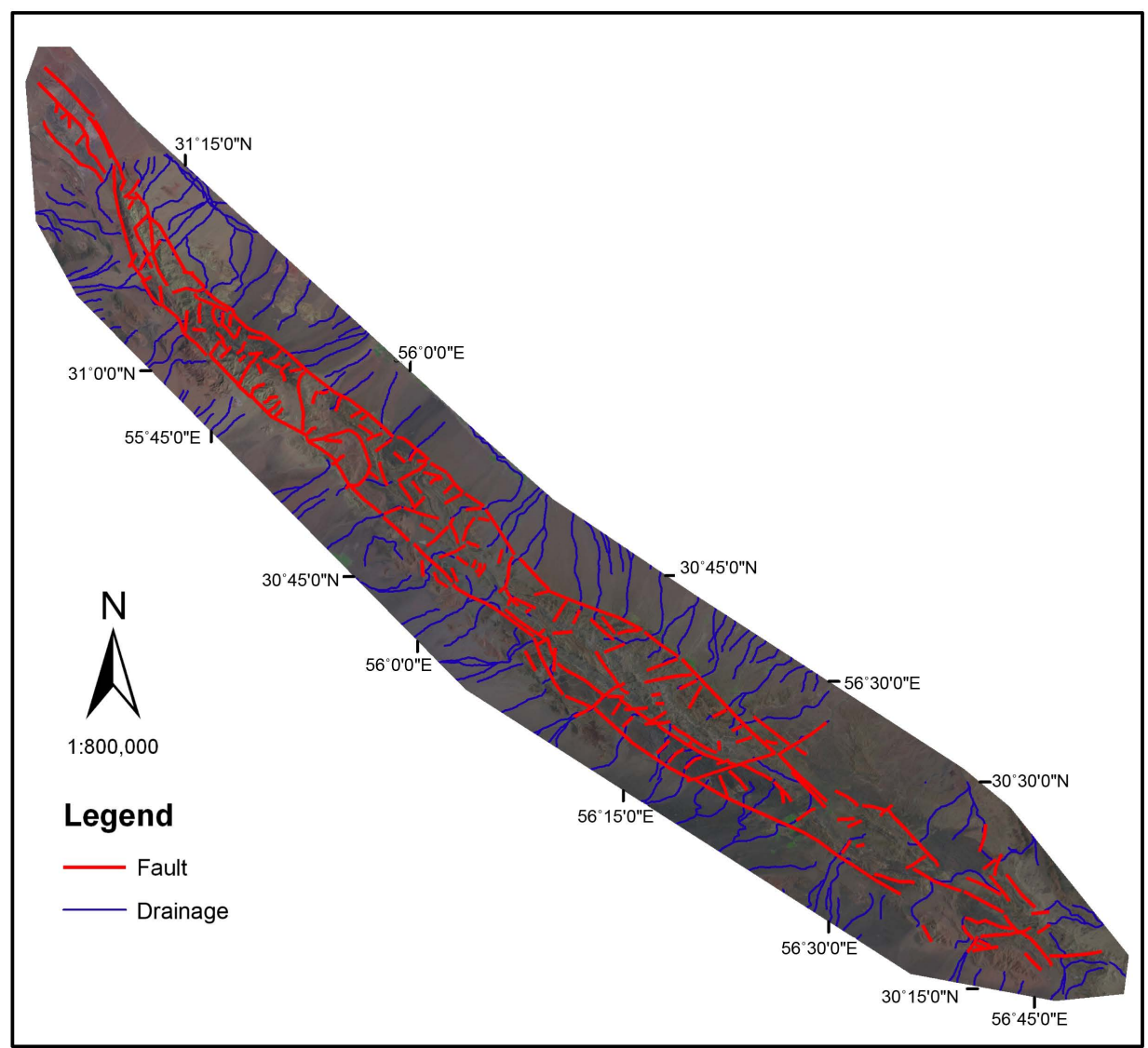

Figure 5. Regional drainages and faults.

line length of the front. Smf is commonly less than 3, and approaches 1 where steep mountains rise rapidly along a fault or fold [95]. Therefore, this index can play an important role in tectonic activity. 


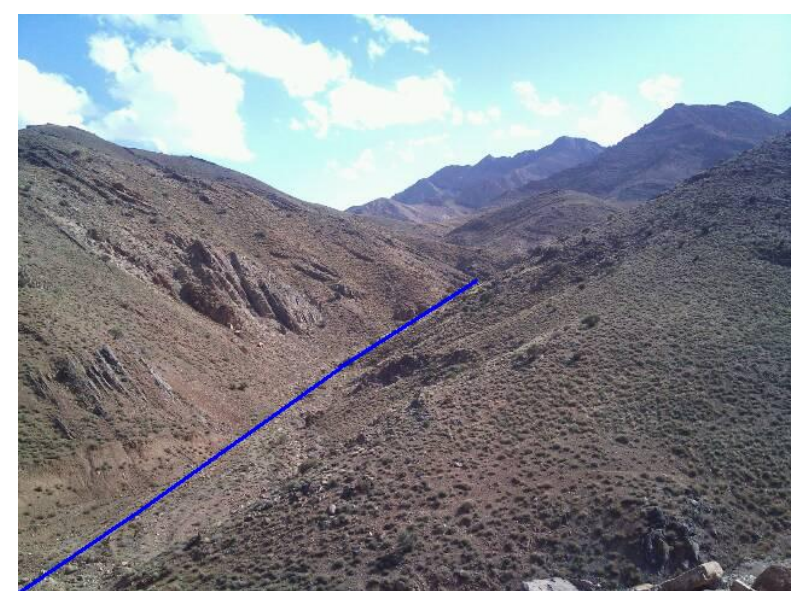

Figure 6. A stream on the NE flank of Davaran Mountain, view to the SW.

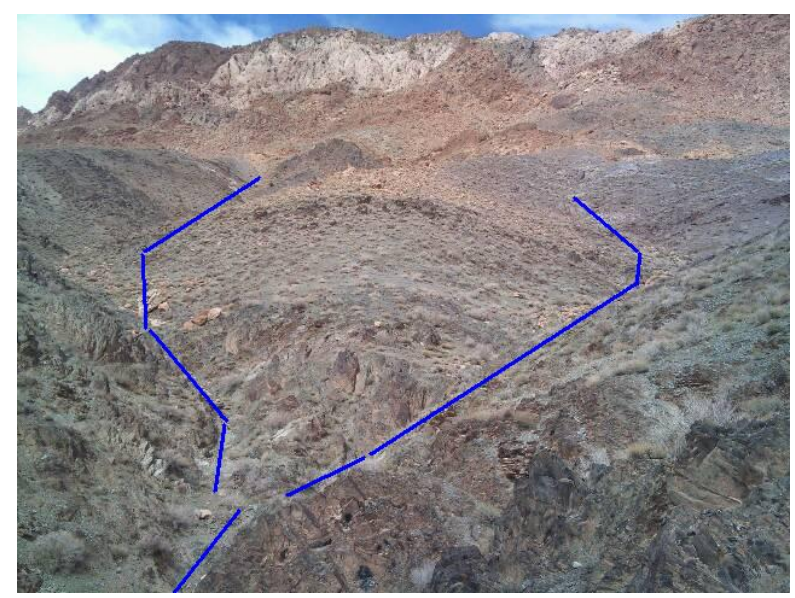

Figure 7. The streams on the SW flank of Davaran Mountain, view to the NE.

\subsection{Valley Floor Width-Valley Height Ratio (Vf)}

This index can separate v-shaped valleys with small amounts from u-shaped valleys with greater amounts. The calculation formula is in this manner:

$$
\mathrm{V} f=2 \mathrm{~V} f w /(\text { Eld }+ \text { Erd }-2 \mathrm{Esc})
$$

where $\mathrm{V} f \mathrm{w}$ is the width of the valley floor, and Eld, Erd and Esc are the altitudes of the left and right divisions (looking downstream) and the stream channel, respectively [95].

High values of $\mathrm{V} f$ are related to low uplift rates i.e. low tectonic activity in which rivers have relatively wide floor. Low values of $\mathrm{V} f$ refer to deep valleys in which rivers drill valleys actively and mainly are related to active tectonic and uplift.

Mountain-front sinuosity (Smf) of active tectonic is $\sim 1$ to 1.6. The sinuosity of mountain fronts with low activity is $\sim 1.6$ to 3 and the sinuosity of inactive mountain fronts is $\sim 3$ to the values higher than 5 ; since erosion is high and tectonic is inactive. Therefore, uplift is not occurred, thus the length of curvature line of mountain front increases.

The sinuosity of both sides of mountain fronts (Smf) (northeast and southwest fronts) and ratio of valley floor width of the rivers of the region to its height (Vf) were calculated based on satellite images and topographic maps. It was specified that the mean sinuosity of northeast front is equal to $\mathrm{Smf}=1.159$ and average $\mathrm{V} f$ index relating to the rivers flowing in the northeast front is equal to 0.756 . The mean sinuosity of south- 
west front is equal to $\mathrm{Smf}=1.303$ (Figure 8) and average $\mathrm{V} f$ index relating to the rivers flowing in the northeast front is equal to 0.511 (Figure 9).

\section{Results and Discussion}

Through strain geometry in simple shear form was found and the direction of R, R' shears, normal (T) and trust faults can be anticipated.

Shear fractures ( $\left.R, R^{\prime}\right)$ form a complementary system in which $R$ fractures are more extensive in comparison with $\mathrm{R}^{\prime}$ fractures while $\mathrm{R}^{\prime}$ shear with the advancement due to first basement fault operation have a fast rotation in comparison with $\mathrm{R}$ fractures and after some degrees of rotation may become locked and inactive. $\mathrm{R}$ ' fractures form only when $\mathrm{R}$ fractures cover each other [96]. P fractures are also formed by decrease in shear resistance of $\mathrm{R}$ fractures.

Since all basement movements are not absorbed by $\mathrm{R}$ fractures and between two shears of $\mathrm{R}$, shortage axis inclines toward the fracture of $\mathrm{R}$ and also between the two covering $\mathrm{R}$ fractures, a small stress field which can be created new shear with an angle of -15 in relation to the main movement [97]. Tension fractures are located in parallel with the shortage axis and they form the semi-angle between R and R'.

The $\mathrm{T}$ faults form vertically to tension force of the region, they have normal mechanism; for this reason, graben occurs on these faults and consequently they become a suitable place for formation of channels and

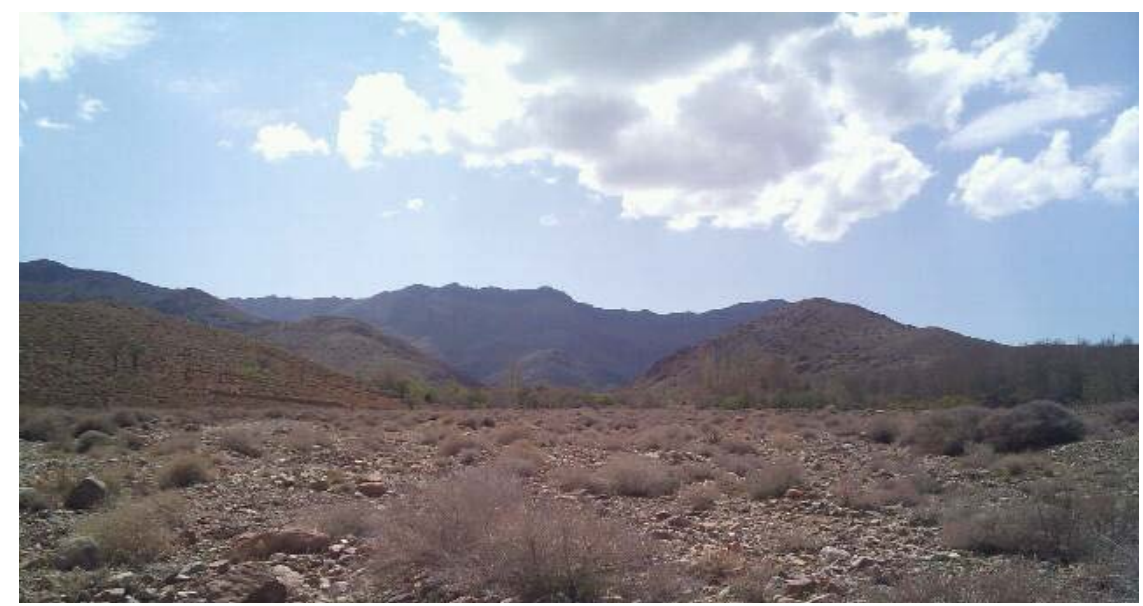

Figure 8. The front of the NE flank of Davaran Mountain, view to the SW.

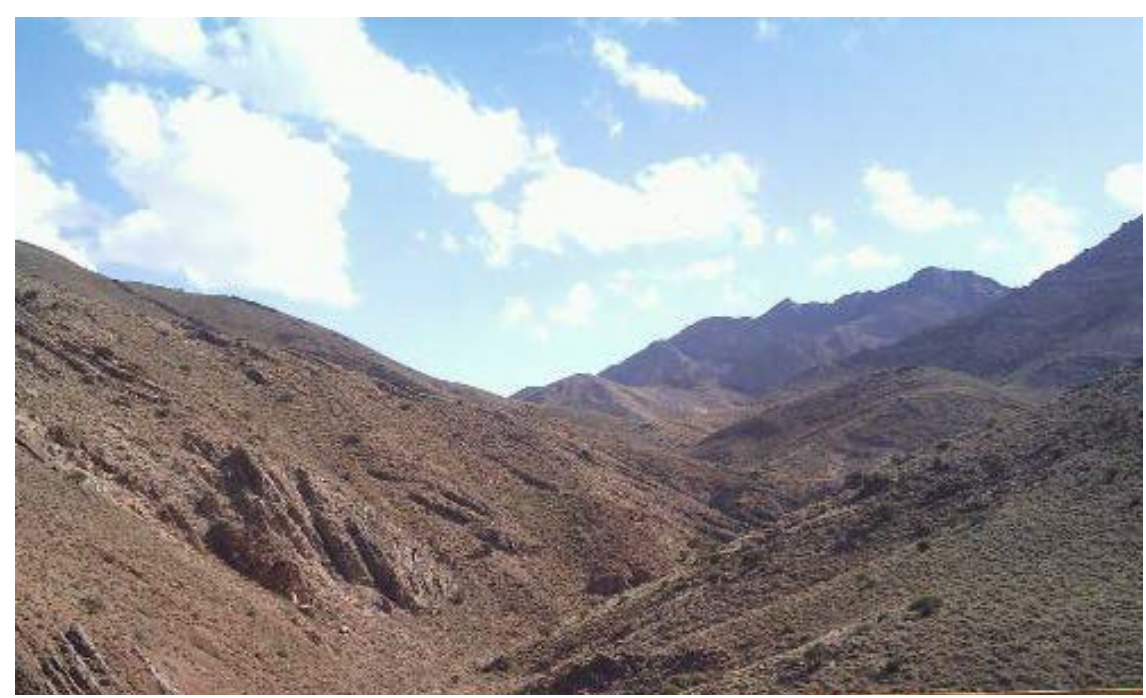

Figure 9. A U-shape valley in the NE flank of Davaran Mountain, view to the SW. 
drainage network. The calculations showed that the northeast front and southwest front of this mountain are active from tectonic aspect and the northeast front has more tectonic activity and uplift with deeper river valleys in comparison with the southwest front.

\section{Conclusions}

Davaran fault system is one of the major faults of the Central Iran and the most important cause for the deformation of the region. High clarity of this fault system sediment cut in the present period which is clearly shown in satellite digital data processing and field observation shows the activeness of this fault system. The most faults in this region, are consist with the expected fractures in the classic transpressional shear zones.

The faults of this region are divided into five groups (Y, R, R', P, T). The T faults are normal and have formed due to tension force. In the trend of these faults, some drainage networks have been formed in this mountain region due to graben of bed rocks. The river calculations of the region indicate active tectonic and uplift in the highlands of this region and most of its rivers especially the rivers of northeast fronts of the highlands have more active tectonics, they have deep valleys with high walls. The maximum stress can be result of the convergence of Arabia plate towards Central Iran plate. This movement occurs from early Neogene after the formation of Red Sea between Africa and Arabian plates. This causes Neotethys to close between Central Iran and Arabian plate which still continues and affects Central Iran, while keeping this region tectonically active.

\section{Acknowledgements}

This work has funded by Islamic Azad University, Tehran, Iran. Also, Special thanks Geological survey of Iran.

\section{References}

[1] Arian, M. (2013) Physiographic-Tectonic Zoning of Iran’s Sedimentary Basins. Open Journal of Geology, 3, $169-177$. http://dx.doi.org/10.4236/ojg.2013.33020

[2] Qorashi, M. and Arian, M. (2011) Tectonics of Iran. Geologic Survey of Iran, Tehran, 336 p.

[3] Arian, M. (2011) Basement Tectonics and Geology of Iran. AsarNafis Press, Qum, 300 p.

[4] Chu, D. and Gordon, R.G. (1998) Current Plate Motions across the Red Sea. Geophysical Journal International, 135, 313-328. http://dx.doi.org/10.1046/j.1365-246X.1998.00658.x

[5] Berberian, M. and King, G.C.P. (1981) Towards a Palaeogeograghy and Tectonic Evolution of Iran. Canadian Journal of Earth Sciences, 18, 210-265. http://dx.doi.org/10.1139/e81-019

[6] McCall, G.J.H. (1996) The Inner Mesozoic to Eocene Ocean of South and Central Iran and Associated Microcontinents, Geotectonics, 29, 490-499.

[7] Dewey, J.F., Hempton, M.R., Kidd, W.S.F., saroglu, F. and Sengor, A.M.C. (1986) Shortening of Continental Lithosphere; the Neotectonics of Eastern Anatolia, a Young Collision Zone. Special Publication of the Geological Society London, 19, 3-39.

[8] Falcon, N.L (1974) Southern Iran: Zagros Mountains. Special Publication of the Geological Society London, 4, 199211. http://dx.doi.org/10.1144/GSL.SP.2005.004.01.11

[9] Devlin, W.J., Cogswell, J.M., Gaskins, G.M., Isaksen, G.H., Pitcher, D.H., Puls, D.P., Stanley, K.O. and Wall, G.R.T. (1999) South Caspian Basin: Young, Cool, and Full of Promise. GSA Today, 9, 1-9.

[10] Jackson, J., Haines, J. and Holt, W. (1995) The Accommodation of Arabia-Eurasia Plate Convergence in Iran. Journal of Geophysical Research, 100, 15205-15219. http://dx.doi.org/10.1029/95JB01294

[11] Jackson, J. and Walker, R. (2001) Offset and Evolution of the Gowk Fault, S.E. Iran: A Major Intra-Continental Strike-Slip System. Journal of structural Geology, 24, 1677-1698.

[12] Arian, M. (2011) A Preface on Salt Diapirism of Iran. AsarNafis Press, Qum, 309 p.

[13] Arian, M. and Noroozpour, H. (2015) The Biggest Salt-Tongue Canopy of Central Iran. Open Journal of Geology, 5, 55-60. http://dx.doi.org/10.4236/ojg.2015.52005

[14] Asadian, F., Pourkermani, M. and Arian, M. (2007) Tectonic Geomorphology of Salt Structures in the GarmsarLasjerd Area. Geographical Research, 39, 75-84.

[15] Pourkermani, M. and Arian, M. (1997) Salt Domes of Central Iran. Journal of Humanities, 3, $29-41$.

[16] Arian, M. (2012) Salt Diapirism and Tectonics. 2nd Edition, AsarNafis Press, Qum, 319 p.

[17] Arian, M. and Noroozpour, H. (2015) Tectonic Geomorphology of Iran’s Salt Structures. Open Journal of Geology, 5, 
61-72. http://dx.doi.org/10.4236/ojg.2015.52006

[18] Asadian, F. and Arian, M. (2009) Identification of Diapiric Provinces of Central Iran through Geological and Geographical Analysis. International Journal of Agriculture Environment \& Biotechnology, 2, 3443-3451.

[19] Arian, M. (2012) Clustering of Diapiric Provinces in the Central Iran Basin. Carbonates and Evaporites, 27, 9-18. http://dx.doi.org/10.1007/s13146-011-0079-9

[20] Pourkermani, M. and Arian, M. (1998) Tectonic Geomorphology of Salt Domes in West of Zanjan Province, Iran, Geographical Research, 47, 44-53.

[21] Arian, M. and Feizi, F. (2010) The Significance of Faulting on the Surficial Spreading of Evaporitic Deposits in the Varamin-Semnan Area. Journal of Earth and Resources, 3, 1-20.

[22] Feizi, F., Arian, M. and Arian, A. (2015) Mud Diapirism on the Makran, Iran: Case Study on the Napag Mud Volcano, Open Journal of Geology, 5, 300-308. http://dx.doi.org/10.4236/ojg.2015.55027

[23] Arian, M. and Khodabakhshnezhad, A. (2015) Sedimentary Environments Can Be Changed by Geotechnology (Case Study: A Morphotectonic Idea for Design of Extensive Artificial Bay on the Iranian Plateau). International Journal of Geosciences, 6, 487-496. http://dx.doi.org/10.4236/ijg.2015.65039

[24] Arian, M. (2011) Middle East Tectonics. AsarNafis Press, Qum, 236 p.

[25] Arian, M. (2010) Applied Seismotectonics. Farazamin Press, Tehran, 304 p.

[26] Arian, M. and Maleki, R. (2008) Neotectonics. Farazamin Research Center, Tehran, 150.

[27] Pourkermani, M. and Arian, M. (1998) Seismicity of Iran. Shahid Beheshti University Press, Tehran, 212.

[28] Pourkermani, M. and Arian, M. (1997) Seismotectonics. Dez Ab Consulting Engineers Company Press, Tehran, 270.

[29] Arian, M. and Aram, Z. (2014) Relative Tectonic Activity Classification in the Kermanshah Area, Western Iran. Solid Earth, 5, 1277-1291. http://dx.doi.org/10.5194/se-5-1277-2014

[30] Mashal, M., PourKermani, M., Charchi, A., Almasian, M. and Arian, M. (2013) Pattern of Structural Geology Underground in Eastern of North Dezfol Embayment. Advances in Environmental Biology, 7, 260-268.

[31] Pazhoohan, M., Arian, M., Ghorashi, M. and Khosrotehrani, K. (2014) A Study of Drainage Pattern Responses to Active Tectonics in Tadvan Region, SW Iran. Geodynamics, 1, 36-41.

[32] Rahimi, N. and Arian, M. (2014) Tectonic Geomorphplogy of Kangavar-Sosangerd Region, West Iran. Advances in Environmental Biology, 8, 119-124.

[33] Arian, M. and Hashemi, A. (2008) Seismotectonic Zoning in the Zagros, Journal of Sciences, 18, 63-76.

[34] Arian, M., Ahmadnia, A., Qorashi, M. and Pourkermani, M. (2002) Structural Analysis of Mengharak Transcurrent Fault System in Zagros, Iran. Special Geo 2002 Conference Issue Geoarabia, 7, 209-210.

[35] Arian, M., Qorashi, M., Pourkermani, M .and Ahmadnia, A. (2003) Fractal Analysis of Mengharak Transcurrent Fault System in Zagros, Iran. Abstracts of Fourth International Conference on Seismology and Earthquake Engineering, Tehran, 12-14 May 2003, 23.

[36] Baharvand, S., Pourkermani, M., Ajalloian, R., Arian, M. and Nouryazdan, A.R. (2010) Seymareh Landslide and Its Role in Environmental and Geomorphologic Changes of the Pole-Dokhtar Area. Journal of the Earth, 4, 13-24.

[37] Abdideh, M., Qorashi, M., Rangzan, K. and Arian, M. (2011) Assessment of Relative Active Tectonics using Morphometric Analysis, Case Study of Dez River (Southwestern, Iran). Geosciences, 20, 33-46.

[38] Arian, M., Qorashi, M., Pourkermani, M. and Ahmadnia, A. (2006) The Structural Significance Kareh Bas Transcurrent Fault System in the Zagros Fold and Thrust Belt. Journal of Geosciences, 15, 126-133.

[39] Arian, M. and Noroozpour, H. (2015) Seismic Activity and Fractal Geometry of Kareh Bas Fault System in Zagros, South of Iran. Open Journal of Geology, 5, 291-299. http://dx.doi.org/10.4236/ojg.2015.55026

[40] Ehsani, J. and Arian, M. (2015) Quantitative Analysis of Relative Tectonic Activity in the Jarahi-Hendijan Basin Area, Zagros Iran. Geosciences Journal, 19, 1-15. http://dx.doi.org/10.1007/s12303-015-0016-3

[41] Arian, M., Qorashi, M. and Ahmadnia, A. (2003) Analysis of Behbahan Shear Zone. Iranian Journal of Geology, 1, 14.

[42] Baratpour, F., Arian, M. and Solgi, A. (2015) Geometric Analysis of Tukak and Kamarun Anticlines on Izeh Zone. Zagros,Geosciences, 24, 191-200.

[43] Arian, M., Ahmadipour, M.R. and Khodaei, K. (2003) The Elements of Fold Style in Soltan Anticline,Northeast of Pole Dokhtar. Iranian Journal of Geology, 1, 1-8.

[44] Omidali, M., Arian, M. and Sorbi, A. (2015) Neotectonics of Boroujerd Area, SW Iran by Index of Active Tectonics. Open Journal of Geology, 5, 309-324. http://dx.doi.org/10.4236/ojg.2015.55028

[45] Noroozpour, H., Arian, M. and Sorbi, A. (2015) Fault Movement Potentials in the Tehran-Semnan Region (North Iran). 
Open Journal of Geology, 5, 281-290. http://dx.doi.org/10.4236/ojg.2015.55025

[46] Arian, M., Maleki, Z. and Noroozpour, H. (2011) Cenozoic Diastrophism and Deformational Events in the East Central Alborz. Journal of Basic and Applied Scientific Research, 1, 2394-2400.

[47] Feizi, F., Arian, A. and Rahmani, R. (2007) Seismotectonic Zoning in the Eastern Part of the Central Alborz. Journal of Sciences, 17, 151-164.

[48] Khavari, R., Arian, M. and Ghorashi, M. (2009) Neotectonics of the South Central Alborz Drainage Basin, in NW Tehran, N Iran. Journal of Applied Sciences, 9, 4115-4126. http://dx.doi.org/10.3923/jas.2009.4115.4126

[49] Arian, M. and Bagha, N. (2012) Active Tectonics of Tehran Area, Iran. Journal of Basic and Applied Scientific Research, 2, 3805-3819.

[50] Bagha, N., Arian, M., Ghorashi, M., Pourkermani, M., El Hamdouni, R. and Solgi, A. (2014) Evaluation of Relative Tectonic Activity in the Tehran Basin, Central Alborz, Northern Iran. Geomorphology, 213, 66-87. http://dx.doi.org/10.1016/j.geomorph.2013.12.041

[51] Arian, M. and Feizi, F. (2005) Application of Geomorphic Indices to the Assessment of Relative Tectonic Activity Levels in the Alborz-Central Iran Border Zone. Journal of Sciences, 15, 378-403.

[52] Arian, M., Bagha, N., Khavari, R. and Noroozpour, H. (2012) Seismic Sources and Neo-Tectonics of Tehran Area (North Iran). Indian Journal of Science and Technology, 5, 2379-2383.

[53] Moghimi, H., Arian, M. and Sorbi, A. (2015) Fault Movement Potential of Marzanabad Area, North Alborz, Iran. Open Journal of Geology, 5, 126-135. http://dx.doi.org/10.4236/ojg.2015.53012

[54] Arian, M. and Pourkermani, M. (2004) Tectonic Elements of South Flank in the East-Central Alborz Mountain. Journal of Sciences (Teacher Training University), 4, 359-368.

[55] Arian, M. and Qorashi, M. (2006) The Movement Potential Evaluation of the Major Quaternary Faults in Alborz-Central Iran Border Zone, from the East of Tehran to the East of Semnan. Journal of Geosciences, 15, 184-188.

[56] Poroohan, N., Pourkermani, M. and Arian, M. (2013) An Assessment of Relationship in F-Parameter and Paleostress Fields in Heterogeneous Lithologies: Roudbar Area (Northwest of Iran). Australian Journal of Basic \& Applied Sciences, 7, 933-942.

[57] Poroohan, N., Poukermani, M. and Arian, M. (2009) An Assessment on Correlations of Seismotectonic Parameters Preceding and Following Roudbar-Manjil Earthquake (Gilan, North of Iran). Australian Journal of Basic \& Applied Sciences, 3, 2643-2652.

[58] Farrokhnia, A.R., Pirasteh, S., Pourkermani, M. and Arian, M. (2011). Geo-Information Technology for Mass Wasting Hazard Zonation: Central-West Alborz-Iran. Disaster Advances, 4, 24-33.

[59] Khavari, R., Ghorashi, M. and Arian, M. (2009) Assessment of Relative Active Tectonics, South Central Alborz (North Iran). EGU General Assembly Conference Abstracts, 11, 1137.

[60] Sorbi, A., Arian, M. and Pourkermani, M. (2009) The Movement Potential Evaluation of the Major Quaternary Faults in Tehran Quadrangle. Journal of the Earth, 19, 176-182.

[61] Feizi, F. and Arian, M. (2006) The Classification of Thrust Fronts in the Alborz-Central Iran Border Zone from the East of Varamin to the East of Semnan. Journal of Sciences, 16, 75-87.

[62] Arian, M. and Feizi, F. (2005) Application of Geomorphic Indices to the Assessment of Relative Tectonic Activity Levels in the Alborz-Central Iran Border zone the Alborz-Central Iran Border Zone. Journal of Science, 15, 378-403.

[63] Arian, M. and Pourkermani, M. (2004) Structural Significance of North Semnan and Attary Faults in Alborz-Central Iran Border Zone. Journal of Science, 14, 4551-4569.

[64] Arian, M. and Pourkermani, M. (2005) Cenozoic Diastrophism and Deformational Events in the Southern Flank of Central-East Alborz. Journal of Faculty Earth Sciences, 10, 43-51.

[65] Arian, M., Pourkermani, M., Qorashi, M. and Ghasemi, M.R. (2003) North Semnan Fault System and Its Role on Basin Division. 8th Symposium of Geological Society of Iran, 4-6 September 2003, 11-17.

[66] Pourkermani, M. and Arian, M. (2001) Structural Geomorphology of Northeastern Kurdistan. Journal of Humanities, 7, 37-48.

[67] Mardani, Z., Ghorashi, M. and Arian, M. (2011) Geomorphic Signatures of Active Tectonics in the Talaghan Rud, Shah Rud and Sefidrud Drainage Basins in Central Alborz, N Iran. Geosciences, 20, 159-166.

[68] Sorbi, A., Arian, M. and Pourkermani, M. (2011) The Application of Geomorphic Indices to the Assessment of Relative Tectonic Activity Levels in Tehran Quadrangle. Journal of the Earth, 6, 1-9.

[69] Khavari, R., Ghorashi, M., Arian, M. and Khosrotehrani, K. (2010) Geomorphic Signatures of Active Tectonics in the Karaj Drainage Basin in South Central Alborz, N Iran. Geosciences, 19, 67-74.

[70] Mousavi, E.J. and Arian, M. (2015) Tectonic Geomorphology of Atrak River, NE Iran. Open Journal of Geology, 5, 
106-114. http://dx.doi.org/10.4236/ojg.2015.53010

[71] Nouri, R., Jafari, M.R., Arian, M., Feizi, F. and Afzal, P. (2013) Correlation between Cu Mineralization and Major Faults Using Multifractal Modelling in the Tarom Area (NW Iran). Geologica Carpathica, 64, 409-416. http://dx.doi.org/10.2478/geoca-2013-0028

[72] Nouri, R., Jafari, M.R., Arian, M., Feizi, F. and Afzal, P. (2013) Prospection for Copper Mineralization with Contribution of Remote Sensing, Geochemical and Mineralographical Data in Abhar 1:100,000 Sheet, NW Iran. Archives of Mining Sciences, 58, 1071-1084. http://dx.doi.org/10.2478/amsc-2013-0074

[73] Nouri, R., Afzal, P., Arian, M., Jafari, M. and Feizi, F. (2013) Reconnaissance of Copper and Gold Mineralization Using Analytical Hierarchy Process in the Rudbar 1: 100,000 Map Sheet, Northwest Iran. Journal of Mining and Metallurgy, 49, 9-19.

[74] Arian, M. and Nouri, R. (2015) Lineament Tectonics and Mineralization in Tarom Area, North Iran. Open Journal of Geology, 5, 115-124. http://dx.doi.org/10.4236/ojg.2015.53011

[75] Feizi, F. and Arian, M. (2011) The Role of Structural Controllers in Geneses of Copper Deposits in 1:50000 Map of SaiinQaleh. Journal of Sciences, 21, 1-10.

[76] Gholamhosein Fard, N., Sorbi, A. and Arian, M. (2015) Active Tectonics of Kangavar Area, West Iran. Open Journal of Geology, 5, 422-441.

[77] Bahiraee, S, Arian, M., Qorashi, M. and Solgi, M. (2015) The Movement Potential Evaluation of the Mosha Fault (the West of Firoozkuh to the Shahrestanak). Geosciences, 24, 123-126.

[78] Bagha, N., Ghorashi, M., Arian, M., Pourkermani, M. and Solgi, A. (2015) Neotectonic Analysis of Mosha-North Tehran Fault Zone, Based on Morphotectonic Features, Central Alborz, Northern Iran. Geosciences, 24, 41-52.

[79] Mosavi, E.J. and Arian, M. (2015) Neotectonics of Tabas Area, Central Iran by Index of Active Tectonics (IAT). Open Journal of Geology, 5, 209-223. http://dx.doi.org/10.4236/ojg.2015.54019

[80] Daryani, N.J., Arian, M. and Omran, N.R. (2015) Tectonics and Mineralization of Copper in the Ardestan-Kahang Area, Central Iran by Remote Sensing, Open Journal of Geology, 5, 188-196. http://dx.doi.org/10.4236/ojg.2015.54017

[81] Arian, M. and Pourkermani, M. (2001) Rivers Morphology and Active Tectonic (Reviewing the Current Status of Ghezel Ozon River in the Province of Zanjan). 5th Conference of Geological Society of Iran, Tehran, 28-30 August 2001, 556.

[82] Eshghi, Z., Arian, M. and Pourkermani, M. (2012) Structural Investigation on the Lak Mining Area (Bueen Zahra) Based on Remote Sensing, Used for Its Mineralization. Journal of the Earth, 6, 145-155.

[83] Arian, M., Toudeshki, V.H. and Noroozpour, H. (2011) Active Tectonics of QezelOzan River Basin, NW Iran. Journal of Applied Environmental and Biological Sciences, 1, 291-295.

[84] Alizadeh, H., Arian, M., Lotfi, M., Ghorashi, M. and Ghorbani, M. (2015) Determination of Porphyry Copper Deposit Locations Using Photo Lineament Factor in Northern Parts of the Dehaj-Sardoiyeh Belt. Geosciences, 24, $247-252$.

[85] Housini Toudeshki, V., Pourkermani, M., Arian, M. and Khosrotehrani, K.H. (2011) Influence of Structures on the Ghezel Ozan River. Geosciences, 21, 55-60.

[86] Housini Toudeshki, V. and Arian, M. (2011) Morphotectonic Analysis in the Ghezel Ozan River Basin, NW Iran. Journal of Geography and Geology, 3, 258-260.

[87] Arian, M. (2015) Seismotectonic-Geologic Hazards Zoning of Iran. Earth Sciences Research Journal, 19, 7-13.

[88] Arian, M., Pourkermani, M., Sistanipour, A. and Noroozpour, H. (2011) Kinematic Significance of Fold- and FaultRelated Fracture Systems in the Rafsanjan's Northeast Highlands (Central Iran). Journal of Basic and Applied Scientific Research, 1, 3398-3406.

[89] Arian, M., Pourkermani, M., Sistanipour, A. and Noroozpour, H. (2011) Seismicity and Fault Segmentation of BafqBaghin Fault System (Central Iran). Journal of Applied Environmental and Biological Sciences, 1, 382-396.

[90] Mosavi, E.J., Arian, M., Ghorashi, M. and Nazemi, M. (2012) Measurments of Geomorphic Indices in Tabas Area, Journal of the Earth, 7, 213-225.

[91] Arian, M. (2010) Earthquake-Fault Hazard Investigations in the Kerman Quadrangle. Journal of Sciences, 19, $176-182$.

[92] Pourkermani, M., Qorashi, M., Arian, M., Sorbi, A., Farokhnia, A. and Solgi, A. (2003) Structural Features in Western Part of the Lut Region. Iranian Journal of Geology, 1, 29-44.

[93] Arian, M., Alizadeh, H. and Noroozpour, H. (2011) Satellite Geometry of Faults and Fractures and Its Relationship with Porphyry Deposits in Northern Parts of Dahaj-Sardoiyeh Belt, South of Iran. Indian Journal of Science and Technology, 4, 1303-1306.

[94] Keller, E.A. and Pitner, N. (2002) Active Tectonics, Earthquakes Uplift, and Landscape. 2nd Edition, Prentice Hall Inc., Upper Saddle River, 362 p. 
[95] Bull, W.B. (2007) Tectonic Geomorphology of Mountains: A New Approach to Paleoseismology. Blackwell, Malden. http://dx.doi.org/10.1002/9780470692318

[96] Tchalenko, J.S. and Ambraseys, N.N. (1970) Structural Analysis of the Dasht-e Bayaz (Iran) Earthquake Fractures. Geological Society of America Bulletin, 81, 41-60. http://dx.doi.org/10.1130/0016-7606(1970)81[41:SAOTDB]2.0.CO;2

[97] Naylor, M.A., Mandl, G. and Sijpesteijn, C.H.K. (1986) Fault Geometries in Basement Induced Wrench Faulting under Different Initial Stress States. Journal of Structural Geology, 8, 737-752. http://dx.doi.org/10.1016/0191-8141(86)90022-2 